УДК 633.15:631.527:632.9

(C) 2012

Харченко Л. Я., науковий співробітник,

Холод С. М., Іллічов Ю. Г., молодші наукові співробітники

Устимівська дослідна станція рослинництва

Інституту рослинництва ім. В. Я. Юр'єва НААН України

\title{
СТІЙКІСТЬ ВИХІДНОГО МАТЕРІАЛУ КУКУРУДЗИ ДО ПУХИРЧАСТӦ̈ САЖКИ ТА ЇЇ ШКІДЛИВІСТЬ У ПІВДЕННОМУ ЛІСОСТЕПУ УКРАЇНИ
}

\section{Рецензент - кандидат сільськогосподарських наук О. В. Тригуб}

\begin{abstract}
Наведена характеристика інтродукованих генотипів кукурудзи за стійкістю до сажкових хвороб. Проведено аналіз ураження 48 зразків кукурудзи різних груп стиглості. Підтверджено даними, щуо основний вплив на розвиток сажкових хвороб кукурудзи мали абіотичні чинники, зокрема, температура повітря та опади. Проведено структурний аналіз врожаю за показниками: маса зерна з початка, кількості зерен, маси 1000 зерен. Істотні втрати зерна спостерігалися при враженні $5 \%$ рослин, а за враження $40 \%$ урожай практично не формувався. Виділено зразки, шоо є джерелами стійкості до пухирчастої сажки, які можна використовувати в селекиії кукурудзи на стійкість до даноїхвороби.
\end{abstract}

Ключові слова: кукурудза, пухирчаста сажка, джерело стійкості, ураженість, шкідливість.

Постановка проблеми. За масштабами поширення, універсальністю використання та енергетичною поживністю кукурудза належить до найбільш важливих продовольчих, кормових i технічних культур на земній кулі. У структурі світового виробництва зерна в останні роки відбулися суттєві зміни, що вивели кукурудзу на провідне місце 3-поміж основних сільськогосподарських культур. В Україні за площею посіву кукурудза посідає третє місце - після пшениці озимої та ячменю ярого, - на неї припадає близько $15 \%$ валового збору зерна [8]. Широкі можливості використання зерна та новітні напрями розвитку переробної промисловості (виробництво біоетанолу та продуктів мікробіологічної промисловості) зумовили збільшення зацікавленості аграріїв України у вирощуванні цієї культури.

Впровадження у виробництво високопродуктивних гібридів кукурудзи та концентрації ऑii площ у спеціалізованих аграрних формуваннях дає не лише збільшення врожайності, а й чимало проблем [11]. Особливу занепокоєність викликає погіршення загального фітосанітарного стану посівів, що супроводжується посиленням шкід- ливої дії хвороб та шкідників культури [5]. В економічній ситуації, що склалася, значення стійких до хвороб сортів і гібридів, - як одного 3 компонентів поліпшення екологічної ситуації й фактора ресурсозберігаючих технологій вирощування, - зростає.

Аналіз основних досліджень і публікацій, у яких започатковано розв'язання проблеми. Створення сортів і гібридів, стійких до патогенів, ведеться в усіх розвинених країнах. У колишньому Радянському Союзі особливо широкі пошукові дослідження у даному напрямі розпочалися 3 робіт М. І. Вавилова [3]. На його думку, «об'єднання в одному сорті стійкості до різних хвороб хоч і складне, але найбільш актуальне питання селекції». Основні проблеми селекції на імунітет полягають у генетичній однорідності вихідного матеріалу, пристосувальній мінливості патогенів, складності взаємовідносин у системі «патоген - хазяїн» $[13,18,12]$.

Одне 3 основних завдань у процесі селекції на імунітет - накопичення максимального розмаїття генофонду за факторами стійкості до хвороб. Сучасна різноманітність сортів і ліній зазвичай дає змогу знайти форми, які служать матеріалом для майбутнього сорту чи гібриду із заданими параметрами. Однак брак інформації про генетику донорів стійкості, які використовуються в селекційних програмах, часто призводить до створення й розмноження однорідних за генотипом сортів і гібридів [17].

Останніми роками в Україні спостерігається погіршення фітосанітарного стану агроценозів, зумовлене впливом екологічних та економічних чинників, що призвело до різкого збільшення рівня чисельності та розширення зон шкодочинності основних хвороб і шкідників. Концентрація посівних площ кукурудзи в спеціалізованих господарствах і в короткоротаційних сівозмінах призводить до накопичення у грунті збудників хвороб, серед яких на особливу увагу заслуговують сажкові хвороби (пухирчаста й летюча). 
За сильного ступеня ураження ними недобір урожаю зерна в господарствах України може становити 15-20\% внаслідок ураження початків, а також через приховані втрати, пов'язані із загибеллю окремих паростків, низькорослістю рослин і недорозвиненістю початків [17]. Негативний вплив шкідників і збудників хвороб зумовлює не лише зниження врожаю зерна чи силосної маси, а й погіршення їх якості.

Найшкодочиннішими хворобами кукурудзи в Україні є летюча та пухирчаста сажки. Збудник пухирчастої сажки кукурудзи - базидіальний гриб Ustilago zeae (Beckm) Unger. Хвороба поширена повсюдно, де вирощують кукурудзу: у Свропі, Азії, Америці, Африці, Австралії. В Україні ця хвороба розповсюджена скрізь, але найбільшої шкоди завдає у напівпосушливих центральних областях степової зони, передусім у вирощуванні сприйнятливих гібридів, уражуючи $10-25 \%$ рослин [16]. На величину втрат урожаю впливає кількість, розмір та розташування пухирів на одній рослині. Пухирі великих розмірів спричиняють втрати урожаю близько $60 \%$ і більше, середньої величини - $25 \%$, невеликі $10 \%[1]$.

Відсутність біологічної стійкості до збудників сажкових хвороб у гібридів викликає необхідність вивчення іммунності матеріалу для вилучення джерел стійкості і впровадження їх у селекційний процес [15].

Окремі автори стверджують, що стійкість кукурудзи до сажкових хвороб значно залежить від походження. Так, М. І. Вавилов у своїх дослідженнях вказав Мексику та Центральну Америку, які є основними центрами впровадження рослин кукурудзи в культуру [4]. Завдяки мінливості, пристосованості й високій урожайності, кукурудза значно розповсюдилася в країнах Старого Світу. Складний еволюційний процес іiї створення сприяв виникненню різноманіття ознак $\mathrm{i}$ формуванню різних типів мінливості. У кожній зоні селекція на імунітет проводилася до тих хвороб, які найбільш розповсюджені та шкодочинні [6].

Стійкість до збудників сажкових хвороб $є$ вкрай складною ознакою, що визначається як морфо-біологічними особливостями рослин, так i їх генетичною структурою. Ті самі сорти, лінії, гібриди в різних умовах відрізняється рівнем стійкості [6].

Мета досліджень та методика їхнього проведення. Метою даної роботи передбачалося комплексне вивчення та оцінка різних за походженням інтродукованих сортів і популяцій кукурудзи на стійкість до пухирчастої та летючої сажки в умовах природного інфікування.

Польові досліди проведені в інтродукційнокарантинному розсаднику та в колекційному розсаднику відділу кукурудзи Устимівської дослідної станції рослинництва IP ім. В. Я. Юр'єва НААН України протягом 2008-2010 років. Агротехніка досліджень відповідала прийнятій у Лісостепу України технології вирощування кукурудзи.

Висівали зразки кукурудзи вручну по дві зернини в кожне гніздо на дворядкових ділянках, iз розташуванням рослин 70 х $70 \mathrm{~cm}$, без повто-

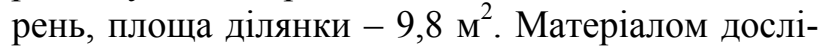
джень слугували зразки кукурудзи, 3 них 16 сортів та 27 популяцій - походженням з Іспанії та Мексики.

Погодні умови для розвитку рослин були такими: період «сівба - сходи» відзначався нестачею суми активних температур у 2008 р. і оптимальними умовами в 2010 році. Розвиток рослин, налив і формування зерна проходили в посушливих умовах 2009 року й сприятливих 2008, 2010 рр. (табл. 1). У цілому погодні умови були сприйнятливими для вегетації кукурудзи.

\section{1. Погодні умови в роки проведення дослідів}

\begin{tabular}{|c|c|c|c|c|c|c|c|c|c|c|c|c|}
\hline \multirow[b]{2}{*}{ Рік } & \multicolumn{4}{|c|}{ Сівба - сходи } & \multicolumn{4}{|c|}{ Сходи - цвітіння волоті } & \multicolumn{4}{|c|}{$\begin{array}{c}\text { Цвітіння волоті - } \\
\text { воскова стиглість зерна }\end{array}$} \\
\hline & 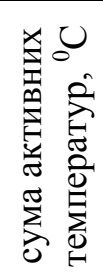 & 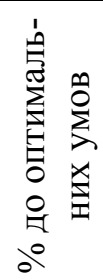 & 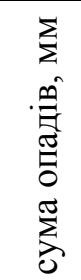 & 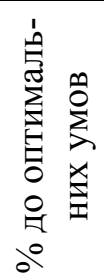 & 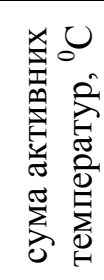 & 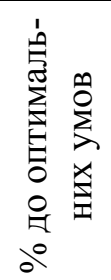 & 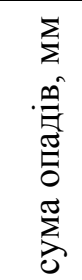 & 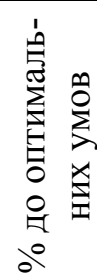 & 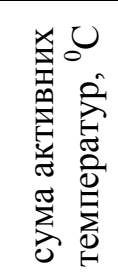 & 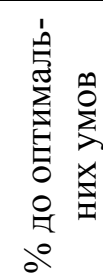 & 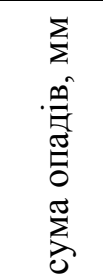 & 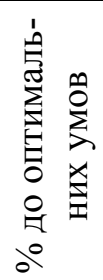 \\
\hline 2008 & 328,4 & $+9,5$ & 65,1 & $-34,9$ & 719,6 & $+2,8$ & 69,2 & $-44,6$ & 1394,2 & $+5,6$ & 123,5 & $+37,2$ \\
\hline 2009 & 336,5 & $+12,2$ & 37,5 & $-62,5$ & 838,9 & $+19,8$ & 31,6 & $-74,7$ & 1359,7 & $+3,0$ & 9,4 & $-89,6$ \\
\hline 2010 & 387,7 & $+29,2$ & 22,1 & $-77,9$ & 843,6 & $+20,5$ & 42,6 & $-65,9$ & 1611,3 & $+22,1$ & 112,2 & $+24,7$ \\
\hline
\end{tabular}


Облік ураження хворобою проводили за п’ятибальною шкалою стійкості 3 градаціями: до 5 \% уражених початків - високостійкі, 5,1-25 \% середньостійкі, 50,1-75 \% - сприйнятливі й понад $75 \%$ - високо сприйнятливі.

Господарсько цінні ознаки (продуктивність 3 однієі рослини, група стиглості та інші) зразків визначали згідно 3 «Методичними рекомендаціями польового та лабораторного вивчення генетичних ресурсів кукурудзи» [10], «Рекомендаций по изучению зарубежных образцов сельскохозяйственных культур на интродукционнокарантинных питомниках» [14]. Розподіляли зразки за групами цінності за класифікаторомдовідником виду Zea mays L [9].

За групами стиглості зразки розподілено таким чином: 9 (18,7\%) середньоранніх, 14 (29,2 \%) середньостиглих, 10 (20,8 \%) середньопізніх, 15 (31,2 \%) пізньостиглих.

Зразки кукурудзи належать до трьох підвидів: кременистий (Indurata), кременисто-зубоподібний (Semidentata) та зубоподібний (Indentata).

Результати досліджень. На розвиток пухирчастої сажки передусім впливають кліматичні фактори - високі температури повітря і недостатня кількість опадів (менше $1 / 2$ норми), особливо в період цвітіння початків - наливу зерна [2].

Визначення впливу опадів і відносної вологості повітря на стійкість кукурудзи до пухирчастої сажки проводилося в період цвітіння початків (липень, I-II декади серпня), коли рослини найбільш сприйнятливі до хвороби. За невеликої кількості опадів та днів із відносною вологістю нижче 40 \% спостерігалося слабке ураження зразків кукурудзи (2009 р.), чергування засухи з невеликою кількістю опадів у 2008, 2010 рр. збільшило розвиток хвороби (табл. 2).

У цілому найбільш сприятливим для розвитку хвороби був 2009 рік, менш сприятливими 2008 та 2010 роки. Інтенсивний розвиток сажкових хвороб на кукурудзі спостерігався впродовж липня - на початку серпня, коли посушливі періоди чергувалися 3 помірним зволоженням, що $\epsilon$ оптимальними умовами для розвитку сажкових хвороб.

Дослідження показали, що у більшості зразків кукурудзи найчастіше уражуються молоді початки та їх рудименти. Останні розміщені в пазухах листків нижче початка i тому їх кількість залежить від числа вузлів на стеблі й висоти закладання початка [7]. Найсильніше уражуються зразки з високим закладенням початка і великою кількістю репродуктивних рудиментів (табл. 3).

Стійкість зразків кукурудзи пов'язана також із триавалістю вегетаційного періоду. Середньоранні та середньостиглі форми 3 низьким закладанням початка, невеликою кількістю репродуктивних рудиментів уражаються менше. Середньопізні та пізні форми з високим закладанням початків i великою кількістю репродуктивних рудиментів уражуються значніше, поскільки їх тканини довше зазнають впливу негативних факторів.

\section{2. Пошкодження рослин кукурудзи пухирчастою сажкою в залежсності від кількості опадів та відносної вологості повітря нижче $40 \%$}

\begin{tabular}{|c|c|c|c|c|c|c|c|c|c|c|}
\hline \multirow{3}{*}{ Роки } & \multicolumn{6}{|c|}{ Кількість опадів по декадам, мм } & \multirow{3}{*}{$\begin{array}{c}\text { Сума } \\
\text { опадів за } \\
\text { періоди, } \\
\text { мм } \\
\end{array}$} & \multicolumn{2}{|c|}{ Кількість днів } & \multirow{3}{*}{$\begin{array}{c}\text { Середня кіль- } \\
\text { кість ураже- } \\
\text { них рослин, } \\
\text { \% }\end{array}$} \\
\hline & \multicolumn{3}{|c|}{ липень } & \multicolumn{3}{|c|}{ серпень } & & & віднос & \\
\hline & I & II & III & I & II & III & & з опадами & $\begin{array}{c}\text { вологістю } 40 \% \\
\text { i нижче }\end{array}$ & \\
\hline 2008 & 73,4 & 27,6 & 3,1 & 0 & 3,0 & 16,0 & 123,1 & 14 & 3 & 7,5 \\
\hline 2009 & 0 & 0 & 0 & 0 & 6,6 & 2,8 & 9,4 & 4 & 8 & 3,5 \\
\hline 2010 & 79,2 & 16,2 & 0,7 & 0 & 2,7 & 3,4 & 102,2 & 11 & 2 & 10,7 \\
\hline
\end{tabular}

3. Уражкеність рослин кукурудзи в залежнності від морфологічних ознак і біологічних властивостей

\begin{tabular}{|c|c|c|c|c|c|}
\hline $\begin{array}{c}\text { Групи зразків за } \\
\text { скоростиглістю }\end{array}$ & $\begin{array}{c}\text { Кількість } \\
\text { зразків }\end{array}$ & $\begin{array}{c}\text { Висота } \\
\text { рослин, } \\
\text { см }\end{array}$ & $\begin{array}{c}\text { Висота } \\
\text { нижнього } \\
\text { початка, см }\end{array}$ & $\begin{array}{c}\text { Кількість ре- } \\
\text { продуктивних } \\
\text { рудиментів }\end{array}$ & $\begin{array}{c}\text { Кількість } \\
\text { уражених } \\
\text { рослин, \% }\end{array}$ \\
\hline Середньоранні & 9 & 168 & 36 & $2-3$ & 4,1 \\
\hline Середньостиглі & 14 & 202 & 48 & $3-4$ & 4,9 \\
\hline Середньопізні & 10 & 284 & 55 & $5-6$ & 8,7 \\
\hline Пізньостиглі & 15 & 319 & 78 & $7-8$ & 18,0 \\
\hline
\end{tabular}


СІЛЬСЬКЕ ГОСПОДАРСТВО. РОСЛИННИЦТВО

4. Динаміка інфікування рослин кукурудзи упродовж вететації, \%

\begin{tabular}{|c|c|c|c|c|}
\hline \multirow[b]{2}{*}{$\begin{array}{l}\text { Групи ліній за } \\
\text { скоростиглістю }\end{array}$} & \multicolumn{4}{|c|}{ Фази розвитку рослин } \\
\hline & $\begin{array}{l}\text { до 5-6-го } \\
\text { листків }\end{array}$ & 6-12 листків & $\begin{array}{c}12 \text { листків - } \\
\text { викидання волоті }\end{array}$ & $\begin{array}{c}\text { Викидання } \\
\text { волоті - } \\
\text { дозрівання }\end{array}$ \\
\hline \multicolumn{5}{|c|}{2008 рік } \\
\hline Середньоранні & 0 & 0 & 1,5 & 2,5 \\
\hline Середньостиглі & 0 & 0 & 2,2 & 2,9 \\
\hline Середньопізні & 0 & 0,5 & 2,8 & 3,1 \\
\hline Пізньостиглі & 0 & 1,1 & 3,2 & 3,5 \\
\hline \multicolumn{5}{|c|}{2009 рік } \\
\hline Середньоранні & 0 & 0 & 1,7 & 3,5 \\
\hline Середньостиглі & 0 & 0 & 2,4 & 3,7 \\
\hline Середньопізні & 0 & 1,5 & 2,9 & 4,8 \\
\hline Пізньостиглі & 0 & 2,2 & 3,5 & 5,5 \\
\hline \multicolumn{5}{|c|}{2010 рік } \\
\hline Середньоранні & 0 & 0 & 1,7 & 2,6 \\
\hline Середньостиглі & 0 & 0 & 2,3 & 3,0 \\
\hline Середньопізні & 0 & 0,7 & 2,5 & 3,5 \\
\hline Пізньостиглі & 0 & 1,2 & 3,2 & 3,7 \\
\hline \multicolumn{5}{|c|}{ У середньому за 3 роки } \\
\hline Середньоранні & 0 & 0 & 1,6 & 2,9 \\
\hline Середньостиглі & 0 & 0 & 2,3 & 3,2 \\
\hline Середньопізні & 0 & 0,9 & 2,7 & 3,8 \\
\hline Пізньостиглі & 0 & 1,5 & 3,3 & 4,2 \\
\hline
\end{tabular}

5. Ступінь уражсення рослин кукурудзи пухирчастою сажкко, 2008-2010 рр.

\begin{tabular}{|c|c|c|c|c|}
\hline $\begin{array}{l}\text { Групи зразків за } \\
\text { скоростиглістю }\end{array}$ & $\begin{array}{l}\text { Високостійкі } \\
\text { (до 5,0 \%) }\end{array}$ & $\begin{array}{c}\text { Стійкі } \\
(5,1-25,0 \text { \%) } \\
\end{array}$ & $\begin{array}{c}\text { Середньостійкі } \\
(25,1-50,0 \%)\end{array}$ & $\begin{array}{c}\text { Сприйнятливі } \\
\text { (більше 50,1 \%) }\end{array}$ \\
\hline Середньоранні & $\begin{array}{c}\text { Menforte, Armariz, } \\
\text { Xermade }\end{array}$ & $\begin{array}{l}\text { Canicouva } \\
\text { Cammbre }\end{array}$ & & \\
\hline Середньостиглі & $\begin{array}{c}\text { Maceda, } \\
\text { La Frangueira } \\
\text { Viana, Guillarey }\end{array}$ & $\begin{array}{c}\text { Prodocabalos } \\
\text { Monfero, } \\
\text { TAMA } 125 \text { OAXA } \\
70\end{array}$ & $\begin{array}{l}\text { Ortigueira } \\
\text { Cee, Foz, } \\
\text { NAYA } 29\end{array}$ & \\
\hline Середньопізні & Lalin, Coristanco & $\begin{array}{l}\text { H POOL } 7 \mathrm{C} 0, \\
\text { H POOL } 29 \mathrm{C} 24 \\
\text { H POOL } 30 \mathrm{C} 23 \\
\text { H POOL } 31 \mathrm{C} 20 \\
\text { H POOL } 1 \mathrm{C} 0\end{array}$ & $\begin{array}{l}\text { NAYA } 54 \\
\text { CHIH } 436 \\
\text { H POOL } 6 \text { C0 }\end{array}$ & \\
\hline Пізньостиглі & H POLL 7 C0 & $\begin{array}{l}\text { H POOL } 2 \text { C0 } \\
\text { H POOL } 3 \text { C0 } \\
\text { H POOL } 4 \text { C0 } \\
\text { H POOL } 5 \text { C0 } \\
\text { H POOL } 8 \text { C0 } \\
\text { H POOL } 9 \text { C0 } \\
\text { H POOL } 0 \text { C0 } \\
\text { H POOL } 12 \text { C0 } \\
\text { POLL } 15 \text { C29 } \\
\text { H POOL } 32 \text { C26 } \\
\text { H POOL } 33 \text { C } 23\end{array}$ & $\begin{array}{c}\text { POLL 16 C28 } \\
\text { H POOL } 34 \text { C23 } \\
\text { H POOL } 17 \text { C34 } \\
\text { H POOL } 18 \text { C } 30\end{array}$ & \\
\hline
\end{tabular}


Нами було визначено, що у польових умовах рослини досліджуваних зразків кукурудзи найбільш сприйнятливі до хвороби від фази 4-6-го листків до початку молочної стиглості, особливо в період розвитку волоті. Більш раннє ураження зустрічається рідко й зазвичай закінчується загибеллю рослини. Ураження пізніше фази молочно-воскової стиглості $€$ незначним або супроводжується несуттєвим ступенем розвитку хвороби (табл. 4).

Визначаючи відсоток уражених рослин пухирчастою сажкою, під час збирання врожаю виявили високу стійкість у певних зразків (табл. 5).

У результаті проведення структурного аналізу зразків кукурудзи було встановлено, що за ураження $5 \%$ рослин у початків утворювалися невеликі здуття (до 2 см у діаметрі), переважно на верхній частині початка. У процесі дозрівання роздувалися обгортки початка під масою зрілих теліоспор. Під час проведення структурного аналізу кукурудзи уражені початки добре озернені, але кількість зерен у них була меншою, ніж у неуражених початків. Маса 1000 зерен у них була на одному рівні $з$ неураженими. Як результат - в уражених зразків спостерігалося незначне зменшення маси зерна з початка.

За враження $10 \%$ рослин спостерігалося розростання здуттів, а також були помітні зміни порівняно зі здоровим початком: довжина менша, порядок розташування рядів зерен зміщений, зерно різної величини й менша його кількість, маса 1000 зерен менша, маса зерна 3 початка також менша, тобто розвиток хвороби на $10 \%$ рослин спричиняв зниження урожайності майже на $50 \%$.

За враження $20 \%$ рослин здуття значно розросталося, зерна, що утворилися під масою теліоспор,

\section{БІБЛІОГРАФІЯ}

1. Баннікова К. В. Пухирчаста сажка кукурудзи та їі шкідливість у північному Лісостепу України / К. В. Баннікова, О. В. Шевчук // Карантин і захист рослин. - 2011. - №4. - С. 15-16.

2. Буга $C$. Ф. Пузырчатая головня кукурузы и условия, способствующие ее распространению / С. Ф. Буга, Т. Н. Жердецкая, А. А. Едчик. - 2007. - №4. - C. 20-25.

3. Вавилов Н. И. Избранные труды: В 5 т. / Т. 4: Проблемы иммунитета культурных растений. М.-Л., 1964.- $516 \mathrm{c}$.

4. Вавилов Н. И. Происхождение и география культурных растений. - Л. : Наука, 1987. - 440 с. 5. Грисенко Г. В., Дудка Е. Л. Методика фитопатологических исследований по кукурузе. - Днепропетровск, 1980. - 61 с.
- дрібні, щуплі. Виповненість початка нерівномірна. Маса зерна з нього за такого рівня ураженості була в середньому на $75 \%$ меншою, ніж на здорових рослинах, а за підвищення інтенсивності ураження до $40 \%$ розмір початка вдвічі менший за здорові. Більшість качанів за такого рівня ураженості взагалі не формують повноцінного зерна. Якщо зерна утворюються, то вони щуплі, маса 1000 зерен досить мала. Внаслідок такого ураження маса зерна з початка зменшувалася на $95 \%$, тобто урожай практично не формувався. За більш інтенсивного ураження (60 \% i більше) замість озерненого початка утворювалася суцільна спорова маса.

Висновки. Основну роль у розвитку сажкових хвороб інтродукованих зразків кукурудзи відігравали температура повітря та кількість опадів. Отже, висока температура й умови, коли періоди достатньої вологи чергуються 3 iї нестачею, більш сприятливі для розвитку пухирчастої сажки, ніж умови систематичного достатнього зволоження. В роки, коли в період вегетації дощі випадають нерівномірно, пухирчастої сажки буває досить багато, а тривалі посухи несприятливі для іiі розвитку. Ураженість рослин завжди більша за низької (40 \% і нижче) або високої (80 \% i вище) вологості повітря, ніж за оптимальної (60 \%). Ураженість початків кукурудзи пухирчастою сажкою впливає на їх довжину, кількість зерен із початка, масу зерен із початка, масу 1000 зерен і висоту рослин. Специфічні погодні умови в роки вивчення (2008-2010рр.) дали змогу виділити джерела й встановити індивідуальну стійкість до пухирчастої сажки на природному фоні інтродукованих зразків кукурудзи походженням з Мексики та Іспанії.

6. Гур'єва I. А., Рябчун В. К. Генетичні ресурси кукурудзи в Україні. - Х. : Магда LTD, 2007. $392 \mathrm{c.}$

7. Диканева Л. А. Устойчивость самоопыленных линий кукурузы к пузырчатой головне // Труды по прикладной ботанике, генетике и селекции. 1973. - Т. 51. - Вып. 1. - С. 184-186.

8. Кириченко В. В., Петренкова В. П., Гур'єва I. М. [ma ін.]. Ідентифікація ознак кукурудзи (Zea mays L.) (навч. посіб.) - Х. : IP ім. В. Я. Юр'єва УААН, 2007. - $137 \mathrm{c}$.

9. Класифікатор-довідник виду ZEA MAYS L. X. : IP, 1994. - 72 c.

10. Методичні рекомендації для польового та лабораторного вивчення генетичних ресурсів кукурудзи (друге видання). - Х. : IP, 2003. - 43 с. 
11. Моргун В. В. Экспериментальный мутагенез и его использование в селекции кукурузы. - К. : Наук. думка, 1983. - 280 с.

12. Падерина Е. В., Чмут Л. Я. Проблемы селекции зерновых культур на иммунитет // Селекция и семеноводство. - 1995. - № 1. - С. 15-18.

13. Расселл Г. Э. Селекция растений на устойчивость к вредителям и болезням: Пер. с англ. - М. : Колос, 1982. -424 c.

14. Рекомендациии по изучению зарубежных образцов сельскохозяйственных культур на интродукционно-карантинных питомниках. - Л., 1999. - С. 31.

15. Чернобай Л. М. Ознакова колекція - джерело стійкості проти сажкових хвороб вихідного матеріалу для селекції кукурудзи в умовах східного Лісостепу України // Генетичні ресурси рослин, 2008, №5. - С. 147-159.

16. Чернобай Л. М. Сажкові хвороби кукурудзи // Агроном. - 2005. - №1. - С. 36-39.

17. Чучмій І. П. Оцінка параметрів екологічної пластичності і стабільності гібридів кукурудзи в Умовах Лісостепу України / I. П. Чучмій, В. Г. Подолян // Зб. наук. праць Уманської с.-г. академії. - К. : Нора прінт, 1997. - С. 33-36.

18. Югенхеймер Р. У. Кукуруза: улучшение сортов, производство семян, использование: Пер. с англ. - М. : Колос, 1979. - 519 с. 